年次大会・抄紙セッションB

\title{
UV 塗エ紙のリサイクル性について
}

ーリサイクル性付与へのアプローチー

日本化薬株式会社化学品研究所進 藤 成人

\section{RECYCLIC PROPERTY OF UV COATING PAPER -Aprroach to develop UV curable resins for recycle-}

Seijin Shindoh

CHEMICALS RESEARCH LABORATORIES, NIPPON KAYAKU CO.. LTD.

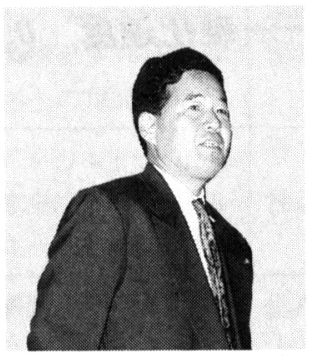

Recently UV curable resins are being used in a wide range of industrial fields. In pulps and papers industry field, progress has been forthcoming in surface coating of paper for carton or jacket. We thought recyclic property of UV curable resins is very important to develop the recycable surface coating paper using these resins. This report describes the approach to develop the UV curable resins for recycl surface coating paper using these resins.

\section{1.はじめに}

近年，放射線硬化型樹脂のコーティング材料の中で, 特にUV 硬化型樹脂の応用分野が拡大している。紙, パルプ分野について見ても紙器類や一部の書籍カバー 等にその需要が年々伸びてきている。

また, 最近の世界的な地球環境保護の高まりの中に あって, UV コーティング材料の紙加工分野への展開 を考える時, コーティング材料のリサイクル性を考虑 に入れなければならない状況にある。

樹脂組成物を構成するモノマー, オリゴマー或いは 光重合開始剤等の研究開発が進み, 一部ではリサイク 儿対応型の UV 硬化型樹脂が実用化されつつある。

\section{2. $\mathbf{U V}$ 硬化型樹脂}

\subsection{UV 硬化システム}

UV コーティング材料は以下のような材料によって
構成されている。

(1)アクリレートモノマー (反応性希瀵剤)

(2)アクリレートオリゴマー (物性の付与)

(3)光重合開始剤（ラジカル反応開始剤）

(4)各種添加剤 (滑り角等の性能付与)

これらの材料を目的にあった組成物に仕上げ，図 1 のような放射線の中の $200 \sim 300 \mathrm{~nm}$ の範囲の紫外線 を照射することにより, 瞬時に高分子膜を作ることの 出きるシステムである。

照射器には図 2 のような種類があり, 加工する材料 によって使い分けている。紙加工品の表面の光沢, 耐 摩性, 滑り性等を向上させることにより, 製品の付加 価值を高めることができるUV 硬化システムの特長 を纏めると以下の如くである。

\section{2 メリット}

(1) 速乾性

(2) 高品質 

進藤成会

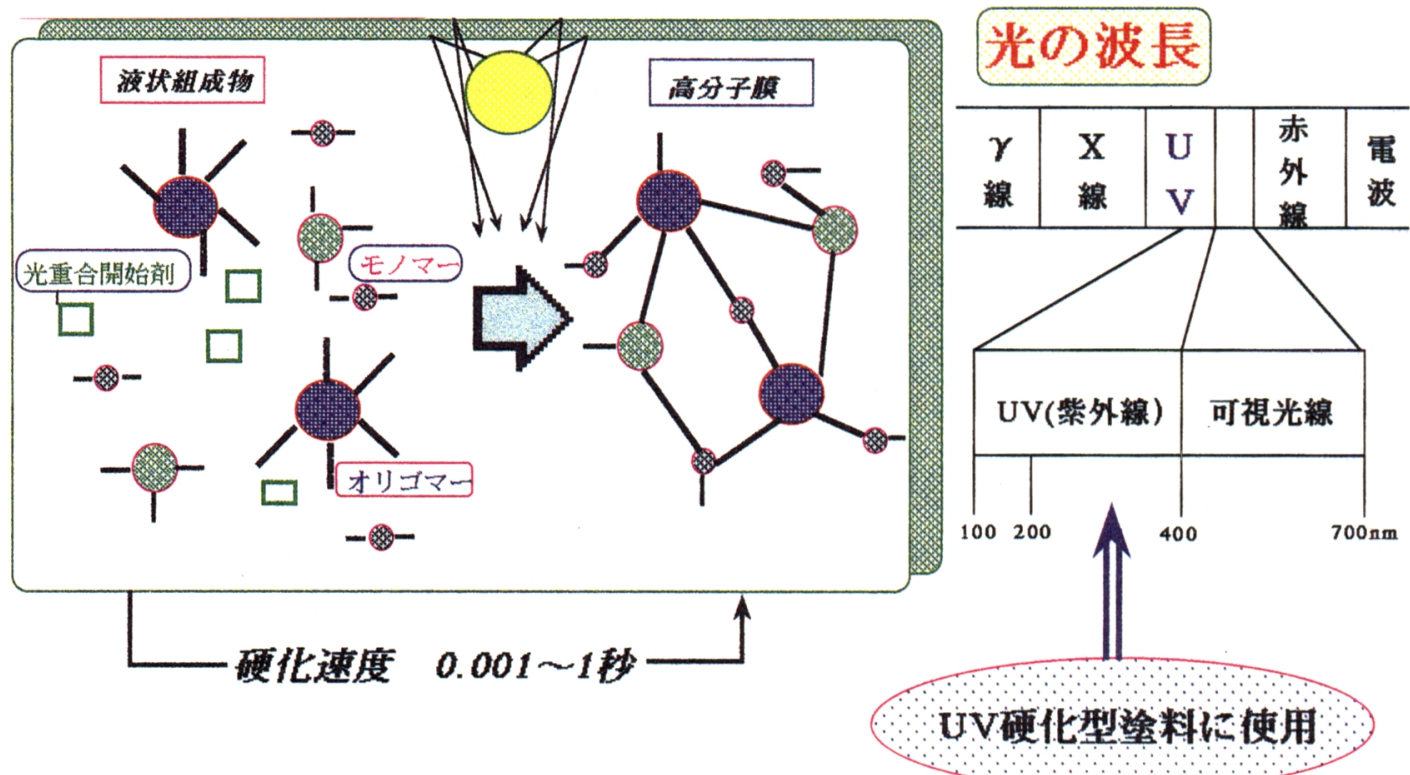

図 1 UV 硬化システム

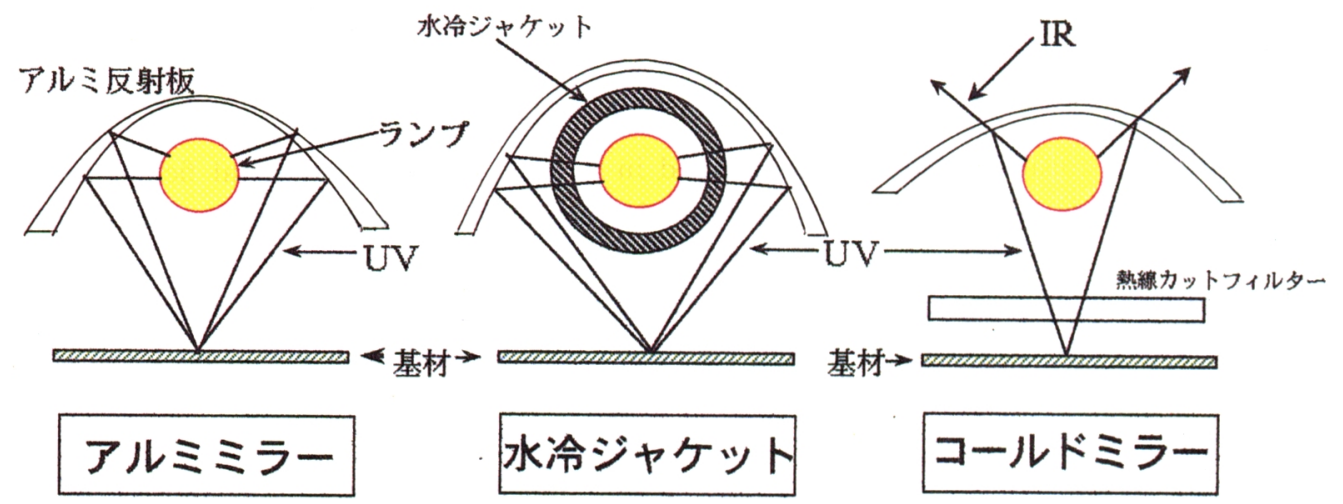

図 2 UV 照射器の違い
(3) 省スペース
(4) エネルギーコストが安い
（5）低温硬化（適用材質の範囲が広い）
（6）既存製造ラインに組み込み易い
(7) システムが単純
2.3 デメリット
(1) 高コスト
(2) 密着性
(3) 皮膚刺激性
(4) 技術的制約（膜厚，酸素禁止作用）

\section{UV 硬化型樹脂の市場}

UV 硬化型樹脂の日本の市場は, コーティング材, インキ, 接着剤, レジスト等の分野で約 $17,000 \mathrm{t} /$ 年 (図3)。米国ではここ 10 年間に 5 倍の伸長率を示し ている(図 4)。

紙加工分野（紙とフィルム, 又はアルミ簿とのラミ ネート, 紙のベースコート, トップコート, 剝離紙等 の高光沢紙分野での市場規模では, 数量で $450 \mathrm{t} /$ 年, 金額では約 9 億门の市場を形成している。 


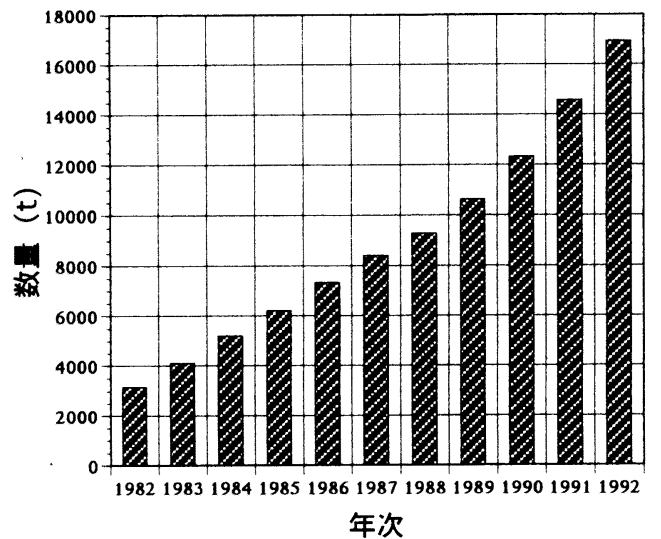

図 $3 \mathrm{UV}$ 硬化樹脂の生産量の推移（日本）

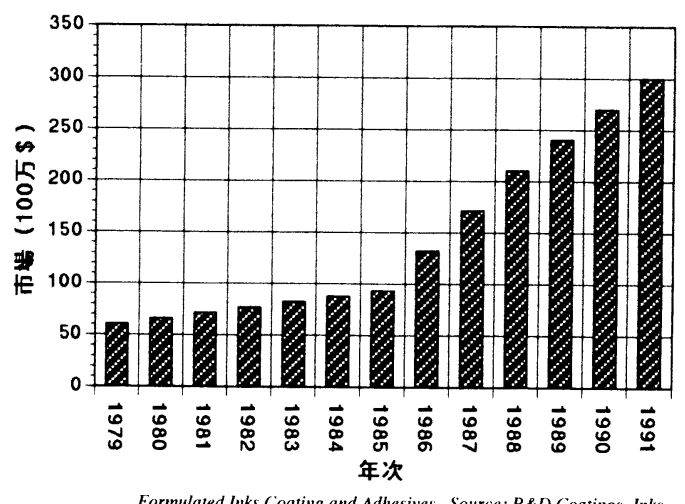

図４アメリカでのラジエーションキュアー市場成 長淬

\section{UV 硬化型樹脂のリサイクル対応}

\section{1 対応方法の分類}

$\mathrm{UV}$ 硬化型樹脂によりコーティングされな紙加工品 のパルプの再生を行う場合, UV 樹脂に要求される性 能は，再生時においてパルプ纎維と容易に分離し且つ 樹脂自体が簡単に分解して繊維の再生に何ら障害を与 えない性質が必要である。

そのカ法としては以下の 3 種に分類することができ る。

種類 一希アルカリ水溶液分解型

\section{水溶性分解型}

一希酸水溶液分解型

一水溶液光重合開始剤

\section{2 希アルカリ水溶液分解型}

実際の紙，パルプの再生処理工程にもつともマッチ した方法として希アルカリ水溶液のよる分解を挙げる
ことができる。希アルカリ水溶液により容易に分解さ れる材料の開発が進んで来ている。大別するとエポキ シ系樹脂と共重合系ポリマーに分類できる。

(1) エポキシ樹脂系

(1) ノボラック型エポキシ樹脂

\begin{tabular}{|c|c|c|}
\hline 例 & 樹脂の種類 & 特 徵 \\
\hline 1 & $\begin{array}{l}\text { ノボラック型エポキシアク } \\
\text { リレートの二塩基付加物 }\end{array}$ & $\begin{array}{l}\text { 現在多量に使用さ } \\
\text { れている }\end{array}$ \\
\hline 2 & 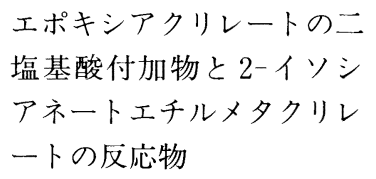 & $\begin{array}{l}\text { 官能基を増やし, } \\
\text { 感度 UP }\end{array}$ \\
\hline 3 & $\begin{array}{l}\text { エポキシアクリレートの二 } \\
\text { 塩基酸無水物とアルキルケ } \\
\text { テンダイマーの反応物 }\end{array}$ & $\begin{array}{l}\text { 水酸基を少なくし, } \\
\text { 密着性 UP }\end{array}$ \\
\hline 4 & $\begin{array}{l}\text { エポキシアクリレートの二 } \\
\text { 塩基酸無水物と TDI-アル } \\
\text { キルアルコールの反応物 }\end{array}$ & $\begin{array}{l}\text { フイラーとの濡れ } \\
\text { 性改良 }\end{array}$ \\
\hline 5 & $\begin{array}{l}\text { エポキシ樹脂とアクリル酸 } \\
\text { とジメチロールプロピオン } \\
\text { 酸の反応物の二塩基酸付加 } \\
\text { 物 }\end{array}$ & $\begin{array}{l}\text { 低酸価で安定性向 } \\
\text { 上 }\end{array}$ \\
\hline 6 & $\begin{array}{l}\text { エポキシ樹脂とアクリル酸 } \\
\text { とカルボン酸含有ブタジエ } \\
\text { ン, アクリルニトリル共重 } \\
\text { 合物の反応物の二塩基酸付 } \\
\text { 加物 }\end{array}$ & $\begin{array}{l}\text { フレキシブル, 屈 } \\
\text { 曲性改良 }\end{array}$ \\
\hline 7 & $\begin{array}{l}\text { エポキシ樹脂とアクリル酸 } \\
\text { とアルキルフェノールの反 } \\
\text { 応物の二塩基酸付加物 }\end{array}$ & 分解性良好 \\
\hline 8 & $\begin{array}{l}\text { エポキシ樹脂のアクリル酸 } \\
\text { と鎖延長剤 (例, ビスフェ } \\
\text { ノール A, ジカルボン酸, } \\
\text { ジイソシアネート) の反応 } \\
\text { 物の二塩基酸付加物 }\end{array}$ & $\begin{array}{l}\text { 高分子化によク， } \\
\text { 耐ブロッキング向 } \\
\text { 上 }\end{array}$ \\
\hline
\end{tabular}

(2) ノボラック型以外のエポキシ樹脂

\begin{tabular}{|r|l|l|}
\hline 9 & $\begin{array}{l}\text { トリスフェノールケ系エポ } \\
\text { キシアクリレートの二塩基 } \\
\text { 酸付加物 }\end{array}$ & \\
\hline 10 & $\begin{array}{l}\text { フルオレンビスフェノール } \\
\text { 系エポキシアクリレートの } \\
\text { 二塩基酸付加物 }\end{array}$ & \\
\hline
\end{tabular}




進藤成会

\begin{tabular}{|c|c|c|}
\hline 11 & $\begin{array}{l}\text { ビスフェノール } \mathrm{A} \text { 型エポ } \\
\text { キシ樹脂のアルコール性水 } \\
\text { 酸基のグリシジルエーテル } \\
\text { 化合物のエポキシアクリレ } \\
\text { ートの二塩基酸付加物 }\end{array}$ & $\begin{array}{l}\text { フレキシブル, 屈 } \\
\text { 曲性, 耐折性 }\end{array}$ \\
\hline 12 & $\begin{array}{l}\text { ビスフェノール F 型エポ } \\
\text { キシ樹脂のアルコール性水 } \\
\text { 酸基のグリシジルエーテル } \\
\text { 化合物のエポキシアクリレ } \\
\text {-トの二塩基酸付加物 }\end{array}$ & $\begin{array}{l}\text { フレキシブル, 屈 } \\
\text { 曲性, 耐折性 }\end{array}$ \\
\hline
\end{tabular}

（2）共重合ポリマー系

共重合ポリマー系は分子中にアルカリ溶解基（例； カルボン酸，フェノール性水酸基）とアクリレート基 を含有する系で構造別に分類すると以下のような種類 が例示される。

(1)

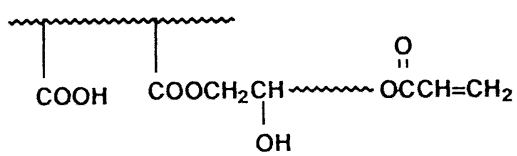

(2)

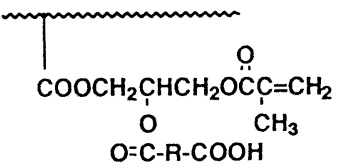

(3)

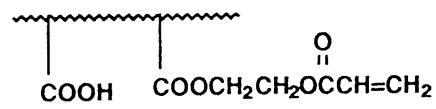

(4)

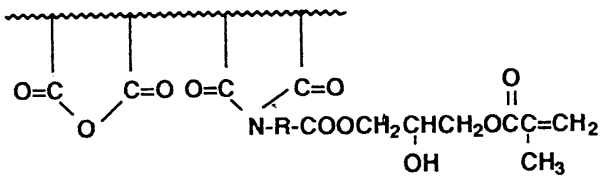

(5)

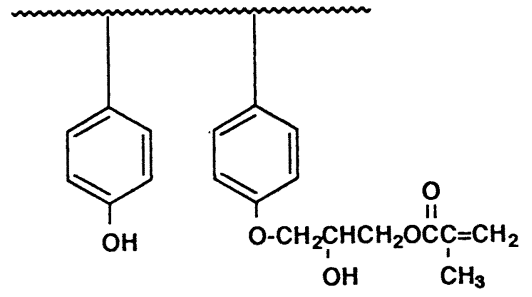

(6)

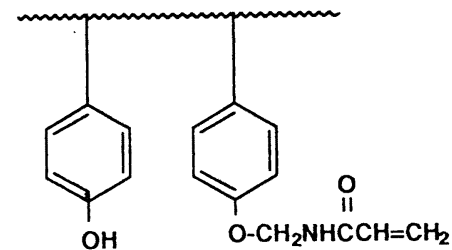

\section{3 水溶性分解型}

環境保護, 作業の安全性から溶剂やアルカリ, 酸を 使用しない水で分解が可能な材料の開発も行われてい る。

エポキシアクリレートの分子中にオニュウム塩基を 導入し水溶性にしており, このオニュウム塩基は加熱 (140 度 $\times 30$ 分) することにより分解が起こる。

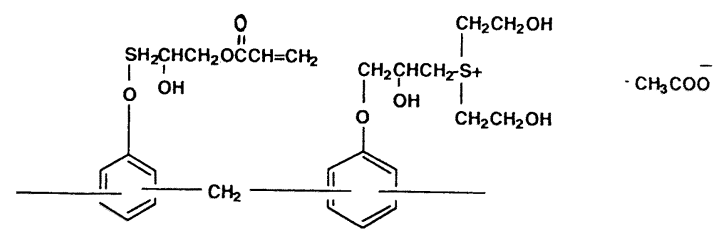

\section{4 希酸水溶液分解型}

最も現実的と思われる希アルカリ水溶液分解型の反 応性オリゴマーは, 分子中に $\mathrm{COOH}$ 基を有しており 硬化膜の耐アルカリ性の点で不十分な側面がある。耐 アルカリ性の改良夕イプで希酸水溶液で（例；1\%リ ンゴ酸）分解する材料も開発されている。

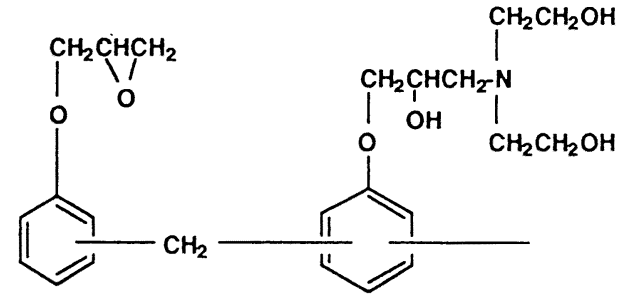

\section{5 水溶性光重合開始剤}

水溶化の方法は，オリゴマー類の方法と基本的に同 様な方法で検討されている。(1)の構造中に四級アンモ ニウム塩を導入することにより水溶性化したもの。

4.5 .1 ベンゾフェノン系
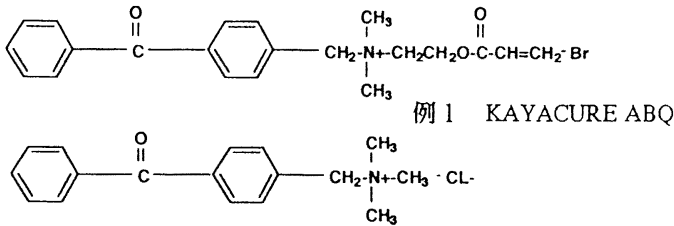

例 2 KAYACURE BTC

4.5 .2 チオキサントン系

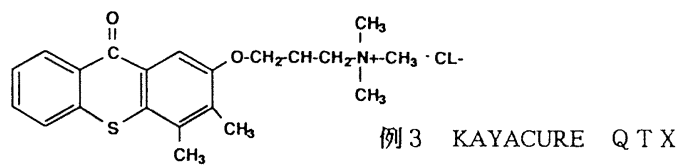

\section{6 従来型とリサイクル対応型の組成比較}

従来のUV 硬化型樹脂は紙の再生処理にあって, 禁忌品の扱いを受けている。これは架橋した高分子膜 
が離解時に分解されずに繊維中に残存することによる。 紹介した材料はこうした流れの中で開発が進められて 地球鉒, パルバー方式では何れもアルカリを用いる工 程があり, 水溶性モノマー, 分解性オリゴマー, 分解 促進性ポリマー, 水溶性光重合開始剤の組み合わせに よりリサイクル性を有したコーティング剤が可能とな る。

\section{5.あとがき}

どのような商品と言えども，資源の有効活用を前提 にした製品開発が必須な環境になって久しい。ここに

\section{いる材料である。}

環境に対応したリサイクル性を有するUV 硬化型 樹脂で，実用化の段階に入りつつも技術的にクリアし なければ成らない点も幾つか挙げられる。使用可能な オリゴマー等の種類が少なく, 用途展開に巾が持てな い。又化審法上の新規物質が多い，等が挙げられる。 環境保護の観点から, 今後の開発は加速度的に進展 するものと考えられる。 